
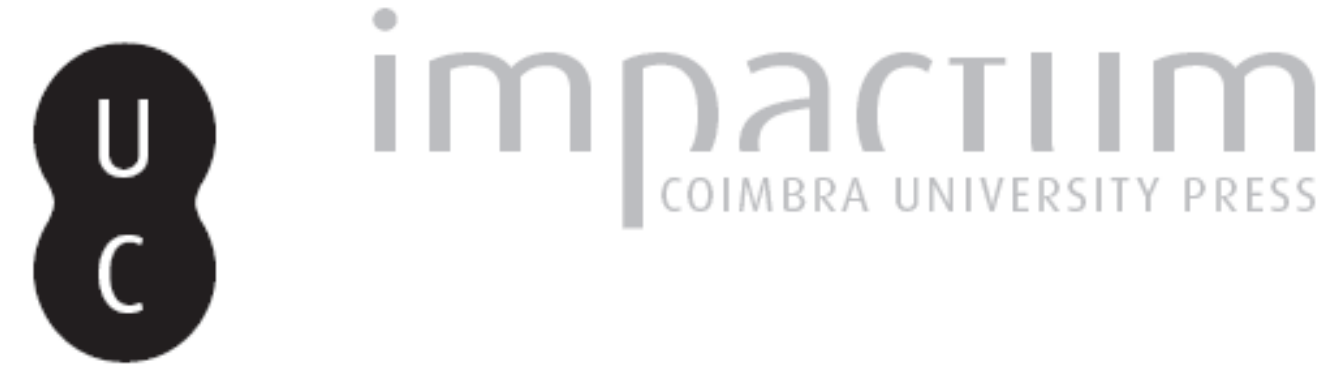

\title{
The New Order of Hitler: virtual history, fiction and myth
}

\section{Autor(es): $\quad$ Neto, Sérgio}

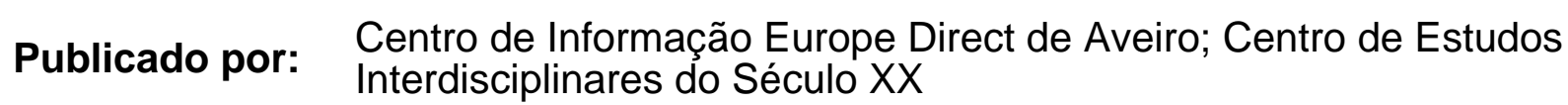

URL

persistente:

URI:http://hdl.handle.net/10316.2/39338

DOI:

DOI:http://dx.doi.org/10.14195/1647-6336_13_7

Accessed : $\quad$ 26-Apr-2023 14:44:54

A navegação consulta e descarregamento dos títulos inseridos nas Bibliotecas Digitais UC Digitalis, UC Pombalina e UC Impactum, pressupõem a aceitação plena e sem reservas dos Termos e Condições de Uso destas Bibliotecas Digitais, disponíveis em https://digitalis.uc.pt/pt-pt/termos.

Conforme exposto nos referidos Termos e Condições de Uso, o descarregamento de títulos de acesso restrito requer uma licença válida de autorização devendo o utilizador aceder ao(s) documento(s) a partir de um endereço de IP da instituição detentora da supramencionada licença.

Ao utilizador é apenas permitido o descarregamento para uso pessoal, pelo que o emprego do(s) título(s) descarregado(s) para outro fim, designadamente comercial, carece de autorização do respetivo autor ou editor da obra.

Na medida em que todas as obras da UC Digitalis se encontram protegidas pelo Código do Direito de Autor e Direitos Conexos e demais legislação aplicável, toda a cópia, parcial ou total, deste documento, nos casos em que é legalmente admitida, deverá conter ou fazer-se acompanhar por este aviso.

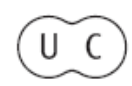


DEBATER

A EUROPA

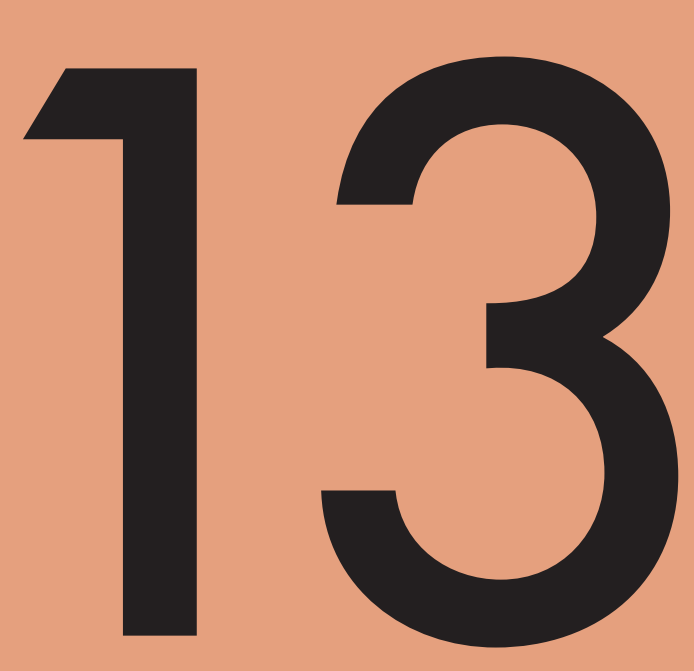

jul-dez 2015
A (DES) CONSTRUÇÃO DA EUROPA
(1939-1945)
(DE) CONSTRUCTING EUROPE (1939-1945) 


\title{
The New Order of Hitler: Virtual History, Fiction and Myth
}

\author{
Sérgio Neto \\ Researcher of CEIS20, University of Coimbra \\ E-mail: sgdneto@gmail.com
}

\begin{abstract}
At the intersection of counterfactual Historiography and literary fantasy, the triumph of the Axis powers in World War II has been one of the main issues. The resurgence of a hypothetical IV Reich also results extensive. Similarly, cinema has not failed to go over the old question of "if". This article intent to analyse some virtual literature and historical works of reference about the New European Order in order to discuss possible inspiration that science awoke this genre and concepts revolving around the revisionism and determinism.
\end{abstract}

Keywords: New European Order; Counterfactuals; Dystopia; Historiography; Fantasy

When the German army completed the conquest of Poland in September 1939 the New European Order began to take shape. The euphemistic name of that brutal military occupation was in fact more incisive than the name given to the Japanese occupied areas: Greater East Asia Co-Prosperity Sphere ${ }^{1}$. But, the main issue was if Hitler's projects achieved in a few years the degree of dehumanization promised by the propaganda with the so called Reich of a Thousand Years. Based on the assumptions outlined by Mein Kampf, as well as the improvisations made during the course of the war, the dreams and fantasies of world domination were analysed not only by the historiography, but widely widespread by the alternate story genre. The vortex of the abyss is somewhat seductive and catches the eye. First, due to a combination between

\footnotetext{
${ }^{1}$ LEBRA, Joyce C. (ed.) - Japan's Greater East Asia Co-prosperity Sphere in World War II. Selected readings and documents. New York: Oxford University Press, 1975.
} 
myth and reality, that since the beginning of the national-socialist regime, was deduced from the exotic interpretations that intertwined swastika and the occult ${ }^{2}$. On the other hand, in the eve of defeat, the Wagnerian finale that Hitler wished for himself and Germany, either by issuing the Nero Decree, or waiting for the arrival of the Soviet army to Berlin, it was in order to dramatize for History the last act of a piece ${ }^{3}$.

Moreover, the most important cinematography about the twilight of the Third Reich did not fail to emphasize, in the claustrophobic atmosphere of the Chancellery bunker, the ultimate reverie of the dictator ${ }^{4}$. Ironically, both Alec Guinness in Hitler, The Last Ten Days (1973), and Bruno Ganz in Der Untergang (2006), look at models of wide streets and huge buildings, which should be constructed after the end of the war in Berlin, while the Russians tighten the final siege of the city. These brief moments of the two films, revolving around the illusions of the New European Order, contrast with the filmography that imagined a victory of the German army. For example, It Happened Here (1965) focus on the collaboration versus resistance of British citizens to an hypothetical Nazi conquest, following a successful Operation Sea Lion. Making use of an almost documentary style, hence the paradox, the film seems to discuss the matter of some British historiography, which postulates that the cases of cooperation versus resistance of the Channel Islands (Jersey and Guernsey) should not be extrapolated to Great Britain ${ }^{5}$. For instance, Fatherland (1994), by the British director Christopher Menaul, also evokes an alternate reality, now extended to the entire European continent. Set in the sixties, this film was based on a homonymous book ${ }^{6}$. In this imagined world, Germania is a superpower stretching from the Atlantic to the Urals. However, the relations with the United States are strained and the Soviet resistance was never broken. Then, a terrible secret kept by the Nazis is revealed: the extermination of the European Jews during the war. Such disclosure will be disastrous for Germania, putting an end to thaw attempts with the United States. The film also claims that Washington will support the Soviet guerrillas.

\footnotetext{
${ }^{2}$ GOODRICK-CLARKE, Nicholas - The occult roots of Nazism. The Ariosophists of Austria and Germany (1890-1935). New York: New York University Press, 1992.

${ }^{3}$ FEST, Joachim - Inside Hitler's bunker. The last days of the Third Reich. New York: Farrar, Strauss and Giroux, 2004.

${ }^{4}$ KERSHAW, Ian - The End. The defiance and destruction of Hitler's Germany (1944-1945). New York: Penguin Press, 2011.

5 ROBERTS Andrew - "Hitler's England: What if Germany had invaded Britain in May 1940", in FERGUSON, Niall (ed.) - Virtual history. Alternatives and counterfactuals. London: Papermac, 1998.

${ }^{6}$ HARRIS, Robert - Fatherland. New York: Random House, 1992.
} 
In literature, for the majority of the works, the Nazis and the Japanese have conquered most or the entire world and there are no remaining powers to confront them. For these fictional works this happens for two kinds of reasons: $1^{\text {st }}$, the major power of the Allies, the United States or the United Kingdom, lost the war and were conquered; $2^{\text {nd }}$, the domestic problems or the prominence of the Anglo-American fascism led them to neutrality. This is the thread of books as the Swastika Night (1937) ${ }^{7}$, The Sound of His Horn $(1952)^{8}$, The Man in the High Castle $(1962)^{9}$, The Ultimate Solution (1973) ${ }^{10}$, December 7, 1941: A Different Path (1995) ${ }^{11}$, In the Presence of Mine Enemies $(2003)^{12}$, The Afrika Reich $(2011)^{13}$, A Kill in the Morning (2014) ${ }^{14}$ and Artam: One Reich, One Race, a Tenth Leader (2014) ${ }^{15}$.

Swastika Night, a futuristic novel written by Katharine Burdekin, under the pseudonym of Murray Constantine, takes place seven hundred years after the Nazism achieved power, at a time when Adolf Hitler is worshipped as a god. The story concentrates on the oppression of women, the marginalization of Christians and the elimination of Jews. This romance - that literary historian Andy Croft has described as "the most original of all the many anti-fascist dystopias of the late 1930s" forgotten for many years, until it was republished in the 1980s.

The Sound of His Horn is a 1952 dystopian time travel/alternative history novel written by the senior British diplomat John William Wall, under the pseudonym of Sarban. This story has as its protagonist the British naval lieutenant Alan Querdillon, who becomes a prisoner of war during the Battle of Crete, during Second World War. After escaping, and travelling through a forest he runs into a barrier of "Bohlen Rays", is knocked unconscious and awakens in a Nazi controlled world at least a hundred years after the War on the estate of the Reich Master Forester, Count Hans von Hackelnberg.

\footnotetext{
${ }^{7}$ BURDEKIN, Katharine - Swastika Night. London: V. Gollancz, 1937.

${ }^{8}$ SARBAN (pseudonym of John William Wall) - The Sound of his Horn. London: Peter Davies, 1952.

${ }^{9}$ DICK, Philip K. - The Man in the High Castle. New York: G. P. Putnam's Sons, 1962.

${ }^{10}$ NORDEN, Eric - The Ultimate Solution. New York: Warner Paperback Library, 1973.

11 ALLEY, David L. - December 7, 1941: A Different Path. Knoxville, Tennessee: Tennessee Valley Pub., 1995.

${ }^{12}$ TURTLEDOVE, Harry - In the Presence of Mine Enemies. London: Penguin, 2004.

${ }^{13}$ SAVILLE' Guy - The Afrika Reich. London: Hodder \& Stoughton, 2011.

${ }^{14}$ SHIMMIN, Graeme - A Kill in the Morning. London: Bantam Press, 2014.

${ }^{15}$ WEISS, Volkmar - Artam: One Reich, One Race, a Tenth Leader. Los Gatos, California: Smashwords Edition, 2014.

${ }^{16}$ HOPKINS, Chris - English Fiction in the 1930s: Language, Genre, History. London: Continuum International Publishing Group, 2006.
} 
After a long journey and a series of fanciful adventures that culminate in the death of the Count, Querdillon manage to slips across and returns to 1943.

One of the most popular alternate history novels is The Man in the High Castle by American writer Philip K. Dick that has given rise to the American television series with the same name, which is currently produced by Amazon Studios. The action of this novel is set in 1962, fifteen years after the end of a fictional longer Second World War (1939-1947). After winning the conflict, the Axis Powers - Nazi Germany and Imperial Japan - rule over the former United States, that has been divided into three parts: the Japanese puppet state of the Pacific States of America, which comprises the former United States west of the Rocky Mountains; a German puppet state that comprises the eastern half of the former United States; and a neutral zone that acts as a buffer between the two areas, called the Rocky Mountain States.

The Ultimate Solution - noted for its particularly grim tone - was written in 1973 by journalist and former interviewer Eric Norden. This novel sets a world where the Axis forces won the Second World War and partitioned the world between them. On the other hand December 7, 1941: A Different Path is a 1995 alternate history novel by David L. Alley, which premises a different course for the Second World War when the Japanese decide to attack the Soviet Union instead of the United States.

The novel In the Presence of Mine Enemies, by American author Harry Turtledove, depicts a world where the United States remained isolationist and didn't participate in the Second World War, thus allowing the victory of the Axis Powers, who divided the world among themselves. However, some years after the war, the Third World War occurred, featuring nuclear weapons used against the United States.

On the other hand, The Afrika Reich is a 2011 alternate history action thriller novel, written by Guy Saville. In this world, the point of divergence occurs when the United Kingdom is defeated by Nazi Germany during the Dunkirk campaign in 1940, forcing Britain to conclude a non-aggression pact with Germany. Due to the influence of an active Colonial Policy Office (KPA), the Nazis carve up a new colonial empire in Africa, extending their racial genocide to Black Africans.

Two of the most recent published works are A Kill in the Morning and Artam: One Reich, One Race, a Tenth Leader. The first story, printed in June 2014, written by Graeme Shimmin, is set in the year 1955. The British prime-minister, Winston Churchill, died in 1941. Great Britain made peace with Germany thus freeing the Nazis 
up to make war on the Soviets. The two sides fought themselves to a standstill, but after Stalin was overthrown in a coup, peace is made. Germany gains the western Soviet Socialist Republics (SSRs), but the core of the Soviet Union still exists. Now the powers are locked in a three-way Cold War for supremacy over the world. The United States and Imperial Japan still exist (Japan never attacked Pearl Harbor), but neither is considered a great power due to lack of will or resources respectively.

In November 2014 was the turn of German scientist and writer Volkmar Weiss publish the story Artam: One Reich, One Race, a Tenth Leader. Volkmar Weiss imagine a world where the first Leader was killed in a plane crash in November 1941. Therefore the Reich didn't declare war on the United States and history took an alternative course. By 2050, Old Europe and much of the world were wallowing in the Great Chaos. After peaking at 9 billion, the world's population dropped to 2 billion. But in 2084, flourishing in the East with its capital city of Reichsburg (formerly Kiev), is the new Reich, Artam, where generations of genetic selection have created a new human race. This elite race, with its Black Corps, has separated itself from the rest of the population, living a life of excess in guarded settlements. Solidifying their group identity is a religion of self-worship and a perpetual defensive war against guerrilla fighters who are funded through East Asia. This upper class considers themselves so superior to the plebs that the increasingly well-organized resistance movement takes them completely by surprise.

My own experience as a high school teacher shows that students often present counterfactual hypothesis, perhaps as a result of many computer games on History consider this possibility. But, surely, we have to distinguish fiction from revisionism. In the computer games, we cannot assume a deterministic approach. Winning or losing is at the reach of a wise or a bad decision. Even games with a solid historical accuracy, as Cossacks European Wars (2001), it can be assumed that the Battle of White Mountain, from the Thirty Years War, could have been lost by the imperial forces. Or that the Italian campaign of Napoleon Total War (2010) could have been won by the Austrians and the Italian militias. The Axis victory in the Second World War is also theme of many computer games. The objective is always to win the major battles and, so to speak, to rewrite History. In Empire Earth (2001) is possible to unleash the Operation Sea Lion. In Axis \& Allies (2004) Stalingrad and El-Alamein are Axis victories, leading the world to a Cold War, like in the mentioned film Fatherland, between Germany and 
the United States. In Turning Point: Fall of Liberty (2008), the inhabitants from the United States face a major Nazi invasion and form an underground resistance, which eventually leads to victory.

All these virtual scenarios belong to fiction. However, the "what if" had always puzzled historians ${ }^{17}$. And the answer has almost always been the same. In his seminal study, E. H. Carr wondered about the "causation in History". He stated:

Last term here in Cambridge I saw a talk to some society advertised under the title "Was the Russian Revolution Inevitable?" I am sure it was intended as a perfectly serious talk. But if you had seen a talk advertised on "Were the Wars of the Roses Inevitable?" you would at once have suspected some joke. [...] When, however, I write about the Russian revolution of 1917 in precisely this way - the only proper way to the historian I find myself under attack from my critics for having by implication depicted what happened as something that was bound to happen, and failed to examine all the other things that might have happened. Suppose, it is said, that Stolypin had had time to complete his agrarian reform, or that Russia had not gone to war, perhaps the revolution would not have occurred; or suppose that the Kerensky government had made good, and that the leadership of the revolution had been assumed by the Mensheviks or the Social Revolutionaries instead of by the Bolsheviks ${ }^{18}$.

In the same way he also stated:

The other source of the attack is the famous crux of Cleopatra's nose. This is the theory that history is, by and large, a chapter of accidents, a series of events determined by chance coincidences, and attributable only to the most casual causes. The result of the Battle of Actium was due not to the sort of causes commonly postulated by historians, but to Antony's infatuation with Cleopatra. When Bajazet was deterred by an attack of gout from marching into central Europe, Gibbon observed that an acrimonious humour falling on a single fibre of one man may prevent or suspend the misery of nations. When King Alexander of Greece died in the autumn of 1920 from the bite of a pet monkey, this accident touched off a train of events which led Sir Winston Churchill to remark that "a quarter of a million persons died of this monkey's bite"19.

The reference of Churchill is probably not a coincidence, because he wrote in the thirties an essay about a hypothetical victory of the South in the American Civil

\footnotetext{
${ }^{17}$ COWLEY, Robert (ed.) - What if? The World Foremost Military Historians imagine what might have been. New York: Berkley Books, 2000.

${ }^{18}$ CARR, Edward Hallett - What is History? London: Macmillan, 1961.

${ }^{19}$ IDEM - ibidem.
} 
$\mathrm{War}^{20}$. This essay was edited in a book entitled If It Had Happened Otherwise, which also included other counterfactual papers. The ironic premise of Churchill is an alternative universe where the historians imagine what would happen to the United States if General Lee had lost the Battle of Gettysburg. In fact, the historians from this world had pointed that the death of General Stonewall Jackson, due to "friendly fire", deprived Lee from his most valuable allied, who certainly wouldn't recommended the launch of the decisive and ill-fated "Pickett's charge" in Gettysburg ${ }^{21}$. John Keegan, an author who wrote about the "what if" in Military History ${ }^{22}$, gave the title "Could the South have survived" to a chapter of one of his books ${ }^{23}$.

This way of looking at the problem was exactly what Carr was warning: that people tended to fantasise about contemporary History, accepting the Antiquity and the Middle Ages as an inalterable reality. The fact is that we know much more details about recent History and each of them sometimes seems to be just a small and innocuous part of a great web. After all, even in October 1917 the Bolsheviks were just a small political party in revolutionary Russia. But Carr also dismissed the Cleopatra's nose principle, which seems very alike the Theory of Chaos. Some critics underlined that Carr failed to predict the development of science and its influence in History ${ }^{24}$. What is History Now?, edited by David Cannadine forty years after the first print of Carr's What is History? as an homage, points that "Cleopatra's nose resembles the butterfly effect" 25.

In France, the influent book by Paul Veyne, Comment on écrit l'Histoire ${ }^{26}$ from 1971, also debated the "causation in History". The arguments of Veyne for the counterfactual analysis are relevant. He clearly asserts that "we never know what shall be the tomorrow. The causality is necessary and irregular; the future is the realm of the contingency". Also important is the concept of retrodiction. In that particular, Veyne says that historians should avoid the search for causes as if the historical process was

\footnotetext{
${ }^{20}$ CHURCHILL, Winston - "If Lee Had Not Won the Battle of Gettysburg", in SQUIRE, J. C. - If It Had Happened Otherwise. London: Longmans, 1931.

${ }^{21}$ KEEGAN, John - The American Civil War. A Military History. London: Vintage Books, 2009.

${ }^{22}$ COWLEY, Robert (ed.) - What if? The World Foremost Military Historians imagine what might have been. New York: Berkley Books, 2000.

${ }^{23}$ KEEGAN, John - The American Civil War.

${ }^{24}$ KAKU, Michio - Parallel Worlds. A Journey through Creation, Higher Dimensions, and the Future of the Cosmos. New York: Anchor Books, 2005.

${ }^{25}$ CANNADINE, David - What is History Now? New York: Palgrave Macmillan, 2002.

${ }^{26}$ VEYNE, Paul - Comment on écrit l'Histoire. Essai d'épistémologie. Paris: Éditions du Seuil, 1971.
} 
irreversible $^{27}$. Furthermore, the French historian claims that, in History, chance, the "great man" and his epoch are non-negligible aspects.

Anyway, it was Niall Ferguson who discussed this subject with more acuity. In the book he edited, Virtual History, the historian enunciated the methodology of the counterfactual analysis:

1) That what really happened was not the most likely outcome - in the opinion of the most enlightened contemporaries;

2) That alternative is based on historical sources and not a mere fantasy ${ }^{28}$.

For a lot of reasons, essays on the counterfactual have been mostly developed by military historians or in military History. Most of the essays from the mentioned book If It Had Happened Otherwise, discusses alternative military scenarios. The same applies to the historical essays of Virtual History about a hypothetical defeat of England and the Soviet Union. Or the text of John Keegan, The Drive for the Middle East, who suggests that an attack from the south, via Syria and Turkey, to the oil fields of Caucasus, would have been more successful than Operation Barbarossa ${ }^{29}$.

Only these brief examples illustrate a panoply of literary, fictional or scientific attempts, in which the "what if" is the guiding principle. The New European Order, deduced from the Nazi occupation of Europe and the German dictator comments, as well as the ruthless repression and cooptation of slave labor in various countries, has become the most debated scenario virtual. The dystopian universe of Orwellian 1984 is always a reminder.

\section{Bibliography}

ALLEY, David L. - December 7, 1941: A Different Path. Knoxville, Tennessee: Tennessee Valley Pub., 1995. ISBN - 1882194160.

\footnotetext{
${ }^{27}$ BOURDÉ, Guy, and MARTIN, Hervé - Les Écoles Historiques. Paris: Éditions du Seuil, 1983.

${ }^{28}$ FERGUSON, Niall (ed.) - Virtual history. Alternatives and counterfactuals. London: Papermac, 1998.

${ }^{29}$ KEEGAN, John - "The Drive for the Middle East, 1941", in COWLEY, Robert (ed) - What If? Berkley: 2000.
} 
BOURDÉ, Guy, and MARTIN, Hervé - Les Écoles Historiques. Paris: Éditions du Seuil, 1983. ISBN - 2020065177.

BURDEKIN, Katharine - Swastika Night. London: V. Gollancz, 1937. ISBN 0935312560.

CANNADINE, David - What is History Now? New York: Palgrave Macmillan, 2002. ISBN - 0333986466.

CARR, Edward Hallett - What is History? London: Macmillan, 1961.

CHURCHILL, Winston - "If Lee Had Not Won the Battle of Gettysburg", in SQUIRE, J. C. - If It Had Happened Otherwise. London: Longmans, 1931.

COLLOTTI, Enzo - La Germania nazista. Torino: Einaudi, 1962.

COWLEY, Robert (ed.) - What if? The World Foremost Military Historians imagine what might have been. New York: Berkley Books, 2000. ISBN - 978-0425176429.

DEUTSCH, Harold C. and SHOWALTER, Dennis E. - If the Allies Had Fallen: Sixty Alternate Scenarios of World War II. Skyhorse Publishing, 2012. ISBN-10 1616085460.

DICK, Philip K. - The Man in the High Castle. New York: G. P. Putnam's Sons, 1962.

DURAND, Yves - Le Nouvel Ordre Européen Nazi: la collaboration politique dans l'Europe allemande (1938-1945). Bruxelles: Complexe, 1990. ISBN - 2870273584.

FERGUSON, Niall - Virtual history. Alternatives and counterfactuals. London: Papermac, 1998. ISBN - 0333647289.

FEST, Joachim - Inside Hitler's bunker. The last days of the Third Reich. New York: Farrar, Strauss and Giroux, 2004. ISBN - 0374135770. 
GOODRICK-CLARKE - Nicholas, Black Sun: Aryan cults, Esoteric Nazism, and the politics of identity. New York: New York University Press, 2002. ISBN - 0814731244.

GOODRICK-CLARKE, Nicholas - The occult roots of Nazism: the Ariosophists of Austria and Germany (1890-1935). New York: New York University Press, 1992. ISBN - 081473054X.

HARRIS, Robert - Fatherland. New York: Random House, 1992. ISBN - 0679412735.

HOPKINS, Chris - English Fiction in the 1930s: Language, Genre, History. London: Continuum International Publishing Group, 2006. ISBN - 0826489389.

KAKU, Michio - Parallel Worlds. A Journey Through Creation, Higher Dimensions, and the Future of the Cosmos. New York: Anchor Books, 2005. ISBN 1-4000-3372-1.

KEEGAN, John - The American Civil War. A Military History. London: Vintage Books, 2009. ISBN - 9780712616102.

KEEGAN, John - “The Drive for the Middle East, 1941”, in COWLEY, Robert (ed) What If? The World Foremost Military Historians imagine what might have been. Berkley: 2000. ISBN - 978-0425176429.

KERSHAW, Ian - The End. The defiance and destruction of Hitler's Germany (19441945). New York: Penguin Press, 2011. ISBN - 9781594203145.

LEBRA, Joyce C. (ed.) - Japan's Greater East Asia Co-prosperity Sphere in World War II: selected readings and documents. New York: Oxford University Press, 1975. ISBN - 0196382653.

MAZOWER, Mark - Hitler's empire: how the Nazis ruled Europe. New York: Penguin Press, 2008. ISBN - 9781594201882. 
NORDEN, Eric - The Ultimate Solution. New York: Warner Paperback Library, 1973. ISBN - 0446751545.

ROBERTS Andrew - "Hitler's England: What if Germany had invaded Britain in May 1940”, in FERGUSON, Niall (ed.) - Virtual history. Alternatives and counterfactuals. London: Papermac, 1998. ISBN - 0333647289.

SAVILLE, GUY - The Afrika Reich. London: Hodder \& Stoughton, 2011. ISBN 1444710648.

SARBAN (pseudonym of John William Wall) - The Sound of his Horn. London: Peter Davies, 1952. ISBN - 0-670-80902-0.

SHIMMIN, GRAEME - A Kill in the Morning. London: Bantam Press, 2014. ISBN 0593073533.

TSOURAS, Peter - Disaster at Stalingrad: an Alternate History. Yorkshire: Frontline Books, 2013. ISBN - 9781783469468.

TURTLEDOVE, Harry - In the Presence of Mine Enemies. London: Penguin, 2004. ISBN 1101212578.

VEYNE, Paul - Comment on écrit l'Histoire. Essai d'épistémologie. Paris, Éditions du Seuil, 1971. ISBN - 2020287781.

WEISS, Volkmar - Artam: One Reich, One Race, a Tenth Leader. Los Gatos, California: Smashwords Edition, 2014. ISBN - 9781310255106. 